\title{
Transmission of Sustained Growth through the Terms of Trade in an Endogenous Growth Model
}

\author{
Carmen Álvarez Albelo ${ }^{\text {¿ }}$ \\ Universidad de La Laguna and CREB \\ Fernando P erera Tallo \\ Universidad de La Laguna and CAERP
}

A ugust 30,2004

\begin{abstract}
A bstract
This paper develops a two-country model of endogenous growth and international trade. In autarky just one of the countries is capable of generating growth. The trade situation may be characterized by complete or incomplete specialization. In either case, international trade transmits sustained growth to the stagnated economy simply because the terms of trade become each time more favorable to this country. The existence of a non-reproducible factor in the country that grows in autarky is crucial to ensure growth transmission. More over, under incomplete specialization the world economy behaves as an integrated economy, and countries converge in per capita income.
\end{abstract}

K eywords: International trade; Endogenous growth; Non-reproducible factors; Transmission of growth; Terms of trade; Convergence

J EL classi..cation: 033, 041, F43.

${ }^{8}$ Cor resp ondence: Carmen Álvarez A lbelo, Departamento de A nálisis Económico, Facultad de Ciencias E conómicas y Empresariales, Universidad de La L aguna; Campus de Guajara, La Hornera s/n, $38071 \mathrm{La}$ Laguna, Santa Cruz de Tenerife, Spain; Telephone: (34) 922317115; Fax: (34) 922317853; E-mail: calbelo@ull.es. 


\section{Introduction}

A strand of the literature on growth and international trade has considered that openness axects growth by impacting the extent of knowledge from abroad (e.g., Grossman and Helpman, 1997)). This view implies that less developed countries posses mechanisms that allow them to absorb at least a part of the technological progress generated in more advanced economies. However, one question that arises from this assumption is whether trade could sow the seeds of permanent growth in absence of any absorption mechanism in countries unable to do so on their own. Findlay (1980) answered yes to this question with a model in which the rich North is represented by the Solow's (1956) framework, and the poor South behaves as Lewis' (1954) economy. In his model the terms of trade behavior enables growth transmission. However, Findlay's framework is quite restrictive, since it assumes constant saving rates, exogenous growth and ..xed wage rate in the South.

In this paper, we develop a two-country endogenous growth model with international trade of intermediate goods and without any external or scale exect. Our model overcomes the restrictive assumptions in Findlay (1980). Countries are identical in everything, except in initial endowment of physical capital, and labor productivity and technology in one of intermediate good sectors. In the autarky situation one of them (country 1) achieves sustained growth, while the growth rate of the second economy (country 2) is nil at long-run. M ore concretely, country 1 is represented by a Lucas (1988)-R ebelo (1991) type of model, while country 2 behaves as the classical Ramsey's. Since the paper is concerned with long-run growth, the analysis limits to the balanced growth path.

At a given point in time, international trade is mutually bene.cial for countries. T he trade situation at long-run may be characterized by complete specialization, or by incomplete specialization of country 1 . In either case, the terms of trade become each time more favorable to country 2, which results in the transmission of sustained growth. The crucial assumption in our theoretical framework to ensure the propagation of growth from country 1 to country 2 is the existence of a non-reproducible factor in the ...sst economy. This implies that country 1 relative prices in autarky strictly decrease over time, which permits a strictly decreasing (increasing) time path for its (country 2's) terms of trade.

Moreover, under incomplete specialization of country 1 the world economy behaves as an integrated economy, and countries converge in per capita income. This ...nding seems to suggest that the traditional close-economy approach for the study of convergence (e.g., Barro and Sala, 1992; Mankiw et.al., 1992; Ortigueira and Santos, 1997) should be reconsidered. In our 
framework, the equalization of all relative prices among countries due to international trade emerges as the mechanism that leads to convergence.

Therefore, our main ..nding is that sustained growth can be transmitted from country 1 to country 2 simply by trading goods, without spillovers or other type of mechanisms of knowledge absorption. Movements in the terms of trade appear as the way of importing growth from abroad. This important role of terms of trade changes for growth has been identi..ed by the empirical literature According to several studies, the terms of trade movements have to be taken into account when measuring T FP and economic growth of countries because, otherwise, the results might lead to inaccurate conclusions. ${ }^{1}$

As Diewert and M orrison (1986) demostrated through a model based on index numbers, an increase in the price of exports relative to imports has an exect that is similar to an increase in total factor productivity (TFP). M ore recently, Kohli (2004) has shown that measures of real GDP understate real gross domestic income when the terms of trade improve. ${ }^{2}$ T his is because an improvement in the terms of trade is treated in national accounts as a price phenomenon, instead of a real phenomenon that is similar to a technological progress. The empirical analysis by Kohli reveals that real GDP growth harshly over- and underestimates growth in real gross domestic income of countries whose terms of trade have signi..cantly worsened and improved, respectively, over the sample period 1980-1996.

Here, we analyze the situation in which openness is the only source of permanent productivity gains for a country. Looking at growth performances of the A sian "miracle economies", this extreme circumstance seems more than just a possibility. The South East A sian countries constitute an interesting case of study, because their extraordinary economic growth was not associated to the growth of TFP, but to factor accumulation (e.g. Kohli, 1997; Y oung, 1995) and openness (Frankel et. al., 1996). Regarding the terms of trade contribution to growth in Asian countries, K ohli (1997) found that it was positive, though rather small on average (lower than $0.4 \%)^{3}$

Nevertheless, one should take into account two aspects when interpret-

\footnotetext{
${ }^{1} \mathrm{~T}$ his aspect is especially relevant when carrying out international comparisons. See K ohli (2004) for a more detailed discussion.

${ }^{2}$ As reported by the Statistics Division of the United Nations, "real gross domestic income measures the purchasing power of the total incomes generated by domestic production (including the impact on those incomes of changes in the terms of trade); it is equal to gross domestic product at constant prices plus the trading gain (or less the trading loss) resulting from changes in the terms of trade."

${ }^{3} \mathrm{~T}$ he author points out that though the terms of trade exects were quite small on average, they were quite large for particular observations. For instance, for the case of South K orea, the cumulated exect during the sample period 1980-1992 amounted to 4.8\% of GDP.
} 
ing Kohli's (1997) results. First, his analysis does not take into account that the improvement in the terms of trade enables a higher physical capital accumulation, which might understate the terms of trade contribution to growth. Second, an improvement in the quality of imported relative to exported goods amounts to an improvement in the terms of trade. Therefore, one should make sure that quality changes are properly treated when measuring trade gains of countries. Unfortunately, this task is far from easy. Goods features are continuously changing because of technological progress. In fact, the faster the technical progress, the more dic cult to capture quality changes of goods when constructing price indexes. ${ }^{4}$

The rest of the paper is organized as follows. Section 2 introduces the model. Section 3 solves for the autarky equilibrium. Section 4 characterizes the trade situation and shows that sustained growth is exported from country 1 to country 2 , and the terms of trade constitute the mechanism of transmission. Section 5 concludes. Lastly, appendices A and B contain details on calculations.

\section{The model}

In this section we .rst describe the basic structure of the model, and then we characterize agents' decisions.

\subsection{Description of the environment}

The framework builds on Ventura's (1997). Time is continuous and endless and the world economy consists of two large countries, $i=1 ; 2$. There is one non-traded ...nal good (..nal good sector) that can be used for consumption and investment, $Y^{i}(t)$; two potentially traded intermediate goods, $X_{z j}^{i}(t)$, $z=1 ; 2$ (sectors 1 and 2), produced in country $i$ (superindex) and used in the ..nal good production of country j (second subindex); and two factors of production, capital, $\mathrm{K}^{\mathrm{i}}(\mathrm{t})$, and labor, $\mathrm{L}^{\mathrm{i}}(\mathrm{t})$, allocated to both intermediate goods production. We assumethat all markets are perfectly competitive, and that imported intermediate goods are perfect substitute for domestic ones. In addition, capital and labor łows among countries are not allowed.

Each country is inhabited by a continuum of identical households or families that is normalized to one. The families are composed of a continuum of individuals of measure one who make decisions jointly. There is no population growth. Each family member is endowed with one unit of time at

\footnotetext{
${ }^{4}$ Lipsey (1994) showed that measures of long-run trends of the terms of trade are very sensitive to the treatment of quality changes.
} 
each period. However, a part of family's members in country 1 own an initial endowment of human capital, while individuals in country 2 do not possess human capital. Individuals endowed with human capital may allocate their time to work or to increase their human capital by investing a part of their et cient time. In country 2 the time is entirely devoted to work.

Countries possess the same ..nal good technology that is represented by a Cobb-Douglas production function with constant returns to scale:

$$
Y^{i}(t)={ }^{i} X_{1 j}^{i}(t){ }^{\phi_{\circledast} i} X_{2 j}^{i}(t){ }^{\phi_{1 i}} ; 0<®<1 ; i ; j=1 ; 2:
$$

Both intermediates in country 2 , and good 2 in country 1 are produced with the same Cobb-Douglas type of technology, that combines unskilled labor (without human capital) and physical capital.

$$
\begin{aligned}
X_{z}^{i}(t) & ={ }^{i} K_{z}^{i}(t){ }^{\Phi}+\tilde{A} i_{L}^{i}(t){ }_{z}^{\Phi_{1 i}}{ }^{i} \tilde{A} ; 0<1+\tilde{A}<1 ; \\
z & =2 \text { if } i=1 \text { and } z=1 ; 2 \text { if } i=2 ; \\
L_{1}^{2}(t) & =I^{2}(t) ; L_{2}^{i}(t)=1 ; I^{i}(t) ; i=1 ; 2 ;
\end{aligned}
$$

where $K_{z}^{i}(t)$ and $L_{z}^{i}(t)$ denote physical capital and labor allocated to sector $z$ in country $i$, and $I^{i}(t)$ denote the number of workers allocated to sector 1 in country i. However, the production of good 1 in country 1 necessarily requires skilled workers (with human capital), though unskilled may also participate in the production process. Thus, the labor input in this sector de. nes as a composite of el cient time and number of workers:

$$
\begin{aligned}
& X_{1}^{1}(t)={ }^{i} K_{1}^{1}(t){ }^{\phi_{1}} i_{L_{1}^{1}(t)}{ }^{\phi_{1 i}{ }^{\prime}} ; 0<1<1 ; \\
& L_{1}^{1}(t)=(H(t))^{\frac{\tilde{A}}{I_{i}} i_{1}{ }^{1}(t)}{ }^{\Phi_{1 i}} \frac{\bar{A}}{1_{i}} ; 0<\tilde{A}<1 \text {; }
\end{aligned}
$$

where $\mathrm{H}(\mathrm{t}$ ) denote aggregate human capital devoted to work (aggregate eq cient time of workers). Notice that this sector is relatively more intensive in labor than sector 2, since a part of physical capital share has been transfer red to human capital.

Countries do not dixer in preferences. The representative family derives utility from the consumption of an aggregate good, $C^{i}(t)$, and maximize its intertemporal utility discounted at a positive rate $1 / 2^{1}$

\footnotetext{
${ }^{5} \mathrm{C}$ urrent utility de..nes as $\ln C^{-}(t){ }^{-}$if $3 / 4=1$.
} 


$$
U(0)=e_{0}^{Z} e^{i / \frac{\left(C^{i}(t)\right)^{1 / 3 / 4}}{i} 1} d t ; 3 / 4>0 ; i=1 ; 2:
$$

At each time period a family receives capital income and labor income, and faces the budget constraint:

$$
K^{i}(t)={ }_{z=1}^{X^{2}}{ }^{i} r_{z}^{i}(t) K_{z}^{i}(t)+w_{z}^{i}(t) L_{z}^{i}(t){ }^{\phi} i C^{i}(t) ; K^{i}(t), X_{z=1}^{X^{2}} K_{z}^{i}(t) ;
$$

where $r_{z}^{i}(t)$ represents interest rate, $w_{z}^{i}(t)$ is the wage, and $L_{z}^{i}(t)$ is de.ned as in (2) and (3). Total human capital that families in country 1 devote to sector 1 is de..ned as the sum over individuals' ec cient time, that is, individual's human capital at $\mathrm{t}, \mathrm{h}(» ; \mathrm{t})$, multiplied by working time at $\mathrm{t}, \mathrm{u}(» ; \mathrm{t})$ :

$$
H(t)=Z_{0}^{Z^{1}(t)} h(» ; t) u(» ; t) d »:
$$

Only a portion of the $\mathrm{I}^{1}(\mathrm{t})$ individuals who work in sector 1 has human capital and, hence, invest a fraction of their ec cient time to accumulate human capital, $u(» ; t)<1$. The rest of workers devote their ent ire unit of time to work, $u(» ; t)=1$. Plugging (6) into the de..nition of $L_{1}^{1}(t)$ in (3), it follows that the contribution of the unskilled to the production process of good 1 limits to increase the number of workers, since their ec cient time is nil.

This formulation also implies that the family does not care about how human capital is distributed among its members, but about the aggregate amount of human capital. Therefore, the measure of individuals with human capital becomes in some sense irrelevant. In fact, there will be unskilled workers in sector 1 whenever they receive the same retribution as in sector 2. If this is the case, human capital of the marginal individual (who has the lowest level of human capital) will be nil $\left(h\left(I^{1}(t) ; t\right)=0\right)$.

By simplicity, we assume that workers produce human capital at home using the same Lucas's (1988) type of technology:

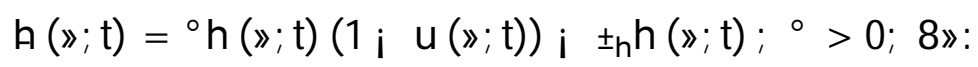




\subsection{Agents' decisions}

To oxer a clearer exposition, we ..rst present a description of agents' decisions that corresponds to an autarky situation. Later on, we will indicate the modi..cations that agents' decisions suxer when the economies are in the trade situation.

\subsubsection{Final good sector}

The maximization of pro..ts in the ..nal good sector implies that intermediate good prices equal marginal productivities:

$$
p_{1}^{i}(t)=\Theta \frac{Y^{i}(t)}{X_{1 j}^{i}(t)} ; p_{2}^{i}(t)=(1 ; \quad \circledast) \frac{Y^{i}(t)}{X_{2 j}^{i}(t)} ; i ; j=1 ; 2 ;
$$

where $p_{z}^{i}(t) ; z=1 ; 2$, denote intermediate good $z$ price in country $i$. The ..nal good price is taken as numerary.

\subsubsection{Intermediate good sectors}

Similarly, interest rate and wage in intermediate good sector 1 and 2 equal physical capital and labor marginal productivities:

$$
\begin{aligned}
r_{z}^{i}(t) & =p_{z}^{i}(t) A \frac{X_{z j}^{i}(t)}{K_{z}^{i}(t)} i \quad t ; \quad w_{z}^{i}(t)=p_{z}^{i}(t) B \frac{X_{z j}^{i}(t)}{L_{z}^{i}(t)} ; \\
i ; z ; j & =1 ; 2 ; \\
A & =1+\tilde{A} \text { and } B=1 ; \quad i \tilde{A} \text { if }(i ; z) \in(1 ; 1) ; \\
A & =' \text { and } B=1 ; \quad \text { if }(i ; z)=(1 ; 1) ;
\end{aligned}
$$

where we assume that physical capital depreciates at the same rate $t_{k}>0$ in both economies.

\subsubsection{Families}

The family's problem in country 1 can be formulated as the maximization of total discounted utility, (4), subject to the budget constraint, (5) and (6), human capital technology, (7), members' initial human capital, $\mathrm{h}(\gg ; 0)>0$; » $2(0 ; ") ; "<1$, and the initial stock of physical capital, $\mathrm{K}^{\mathrm{i}}(0)>0$. As it is usual, we assume that families have perfect foresight and, hence, they can advance time sequences of all prices in the economy, and take them as 
given when solving their problem. The ..rst order conditions for the case of interior solution are the constraints of the problem and: 6

$$
\begin{aligned}
& { }^{i} C^{1}(t)^{\phi_{i}^{3 / 4}}=,{ }^{1}(t) ;
\end{aligned}
$$

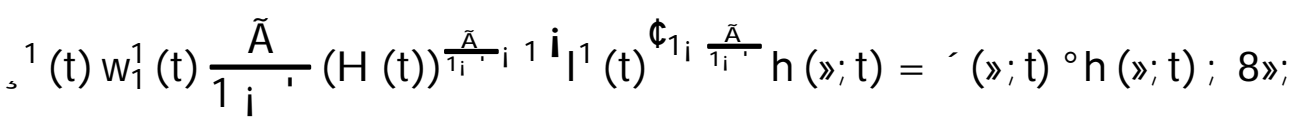

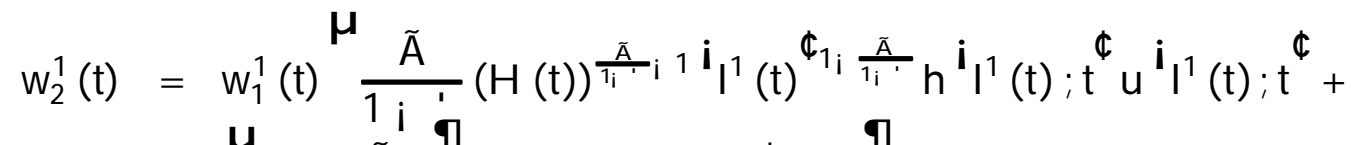

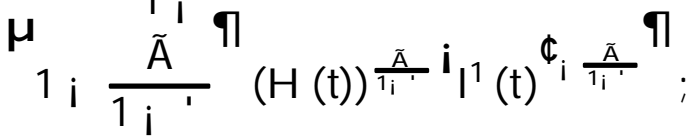

$$
\begin{aligned}
& r_{2}^{1}(t)=r_{1}^{1}(t) ; \\
& \sigma^{1}(t)={ }_{,}^{1}(t) i_{1 / 2 i} r_{1}^{1}(t)^{\phi} ;
\end{aligned}
$$

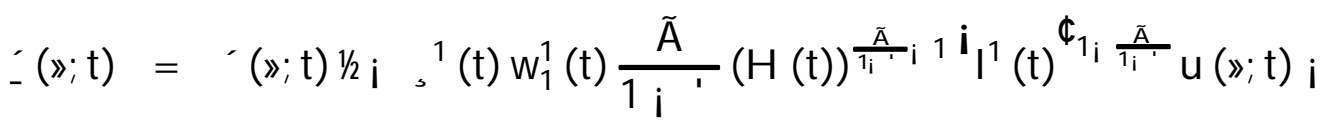

$$
\begin{aligned}
& \text { ' }(\gg ; t)\left({ }^{\circ}(1 ; u(» ; t)) \text { i } t_{h}\right) \text {; }
\end{aligned}
$$

where ${ }^{1}(\mathrm{t})$ and ${ }^{\prime}(» ; \mathrm{t})$ are discounted shadow prices for physical capital (wealth) and individual human capital, respectively. These ..rst order conditions, together with initial endowments of physical and human capital and the usual transversal ity conditions fully characterize the dynamics of country 1.

The interpretation of the ..rst order conditions is standard. However, the workers' al location condition, equation (12), deserves some comments. This condition says that the contribution to family's earnings of the last member allocated to sector 1 and 2 must equalize. Note that the wage of an individual who works in sector 1 has two parts: the retribution that corresponds to his

\footnotetext{
${ }^{6} \mathrm{~T}$ he concavity of both objective function and the const raints guarantee that the necessary conditions are also su $\pitchfork$ cient.
} 
ed cient time, plus that for increasing the number of workers. Hence, the ..rst part vanishes if the marginal individual has zero human capital. In what follows, we will work under the assumption $\mathrm{h}\left(\mathrm{I}^{1}(\mathrm{t}) ; \mathrm{t}\right)=0$.

The household's problem of country 2 immediately follows from country 1 's, since the only dixerence is the absence of human capital. Therefore, the ..rst order conditions of country 2 reduce to the budget constraint and:

$$
\begin{gathered}
{ }^{i} C^{2}(t){ }^{\phi_{i} 3 / 4}={ }^{2}(t) ; \\
w_{2}^{2}(t)=w_{1}^{2}(t) ; \\
r_{2}^{2}(t)=r_{1}^{2}(t) ; \\
{ }^{2}(t)={ }^{2}(t){ }_{1 / 2 i} r_{1}^{2}(t) ;
\end{gathered}
$$

where ${ }^{2}(t)$ is the discounted shadow price of physical capital.

\section{Autarky}

This section characterizes the autarky equilibrium. The competitive equilibrium is as a set of allocations and prices that satisfy ..rms and households problems, and that clear all markets in both economies. Since the results can be obtained by applying straightforward techniques, we opt to restrict all details on calculations to appendix $A$.

The assumptions made in the previous section imply that the number of workers in country 1 becomes a non-reproduci ble factor. As shown by Rebelo (1991), the requirement for sustained growth in presence of non-reproducible factors is the existence of at least one capital good that is produced with a constant returns to scale technology in reproducible factors. Since this is the case for human capital technology, country 1 enjoys perpetual growth. Country 2, however, is represented by Ramsey model and does not grow at long-run.

In both economies, physical capital and workers are allocated so that interest rate and wage (of unskilled in country 1 ) equalize among sectors. This equal ization yields: 


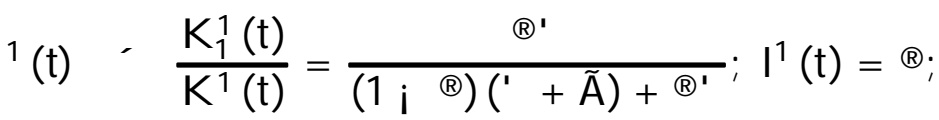

$$
\begin{aligned}
& { }^{2}(\mathrm{t}), \frac{\mathrm{K}_{1}^{2}(\mathrm{t})}{\mathrm{K}^{2}(\mathrm{t})}={ }^{\circledR} ; \mathrm{I}^{2}(\mathrm{t})=\circledast ; \text {; }:
\end{aligned}
$$

The long-run equilibrium of country 1 is characterized by a balanced growth path (BGP), or situation in which physical and human capital, and consumption grow at a constant rate and the time assignment remains unaltered. Moreover, the time assignment is identical for each family's member, $u(»)=u$ 8», since the family only cares about aggregate human capital. From now on, the omission of time will denote stationary values over the BGP.

Given the existence of a non-reproducible factor in country 1, sustained growth is only possible when the engine of growth (human capital) grows at a faster rate than the other per capita variables. Imposing that interest rate must be constant over the B GP, we check that physical capital, consumption and gross income (..nal good production) grow at a lower rate $\mu$ than human capital, $\mu_{H}=\mu_{h}$. T hus, long-run growth rates of country 1 equal:

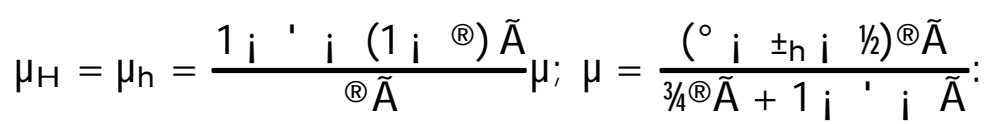

The time allocation betwen work and human capital production comes from the law of motion of human capital:

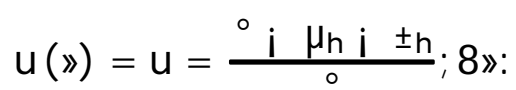

Lastly, we solve for autaky prices, which will permit us to determine the specialization pattern of countries at long-run. Relative prices come from pro..ts-maximizing behavior of ..rms in ..nal and intermediate goods sectors:

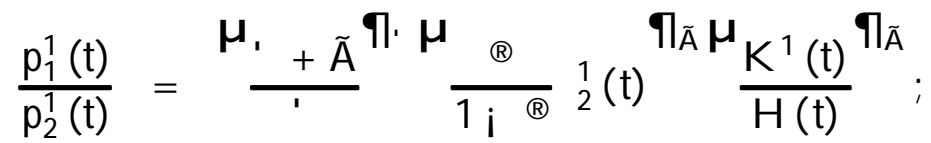

$$
\begin{aligned}
& \frac{p_{1}^{2}(t)}{p_{2}^{2}(t)}=1 ; 8 t ;
\end{aligned}
$$

Note that relative prices in country 1 strictly decrease over time because of the existence of a non-reproducible factor. 


\section{Trade}

In this section we show that sustained growth is transmitted from country 1 to country 2 simply by trading in intermediate goods, and that the terms of trade constitute the mechanism of transmission. As it will be clear later, the existence of a non-reproducible factor in country 1 results crucial to ensure the propagation of growth.

From expression (23), it follows that country 1 and 2 eventually have comparative advantage in the production of intermediate good 1 and 2 , respectively. Next, we show that the trade situation at long-run may be characterized by either complete specialization or incomplete specialization of country 1. All technical details are con..ned to appendix B.

\subsection{Complete specialization}

Under complete specialization, conditions (12), (13), (17) and (18) in family's problem disappear, sincethe resources of country 1 and 2 are entirely devoted to produce good 1 and 2, respectively.

The equilibrium in the trade balance, $p_{1}(t) X_{12}^{1}(t)=p_{2}(t) X_{21}^{2}(t)$, and the maximization of pro..ts by ..rms in the ..nal good sector allow to obtain exported-imported amounts of intermediates by countries:

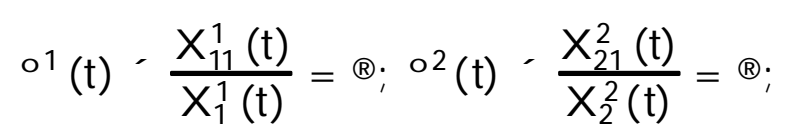

Expression (24) implies that the international relative prices can be written as $\frac{p_{1}(t)}{p_{2}(t)}=\frac{\circledast}{l_{i} \otimes} \frac{X_{2}^{2}(t)}{X_{1}^{1}(t)}$, and gross world income (world production of ...nal good), $\mathrm{Y}(\mathrm{t})=\mathrm{Y}^{1}(\mathrm{t})+\mathrm{Y}^{2}(\mathrm{t})=\left(\mathrm{X}_{1}^{1}(\mathrm{t})\right)^{\circledR}\left(\mathrm{X}_{2}^{2}(\mathrm{t})\right)^{{ }^{1}{ }^{\circledR}}{ }^{\circledR}$, is split between country 1 and 2 in the proportions ${ }^{\circledR}$ and $1_{i}{ }^{\circledR}$, respectively:

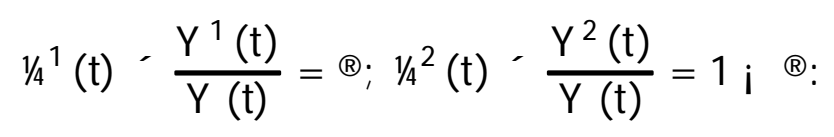

Interest rate in both economies must be constant at long-run, which requires that physical capital, consumption and gross income in the two economies grow at the same constant rate $\mu$, and human capital grows at the

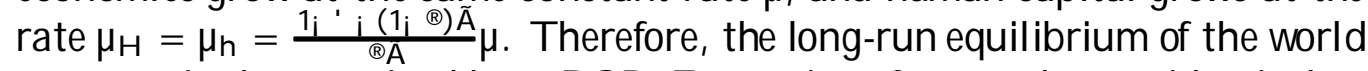
economy is characterized by a BGP. Expressions for $\mu$ and $u$ are identical to those in (21) and (22), respectively.

Thefact that consumption grows at the same rate in both economies leads

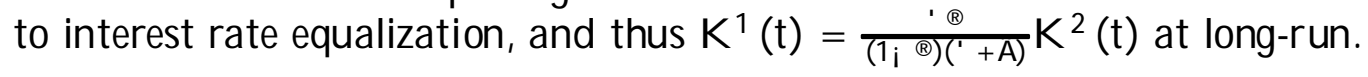


This latter result permits to obtain the expression for the terms of trade over the BGP :

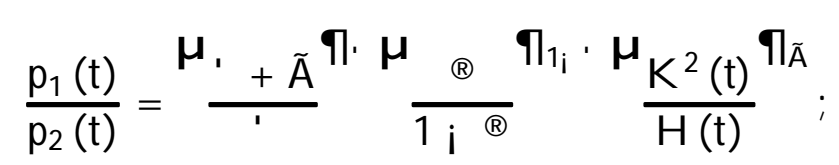

where the omission of superindex i denotes international prices. Theincreases of labor productivity in country 1 makes intermediate good 1 relatively more abundant than intermediate good 2, which makes the terms of trade each time more favorable to country 2 .

Of course, trade under complete specialization will hold over time only if the international relative prices in (26) are greater or equal to country 1's autarky prices. Notice that this might occur, since country l's autarky prices also present a downward sloping time path. This is why the existence of a non-reproducible factor in country 1 results crucial for the propagation of growth.

The decrease in the terms of trade is the mechanism through which country 2 imports sustained growth from country 1 . In exect, considering interest rate of country 2 over the BGP and dixerentiating respect to time, it follows that:

$$
\begin{aligned}
r^{2} & =p_{2}(t)\left({ }^{\prime}+\tilde{A}\right){ }^{i} K^{2}(t){ }^{\Phi}+\tilde{A}_{i} i_{i} \pm_{K} ! \\
\frac{K^{2}(t)}{K^{2}(t)} & =\frac{1}{1 i^{\prime} i \tilde{A}} \frac{\underline{p}_{2}(t)}{p_{2}(t)}=\frac{\Theta \tilde{A}\left(\mu_{H} i \mu\right)}{1 i^{\prime} i \tilde{A}}=\mu:
\end{aligned}
$$

Thus, the introduction of international trade propagates permanent growth to country 2 in spite of not being capable of growing permanently on its own. It is obvious from expressions (26) and (27) that growth is generated by an improvement in the terms of trade of country 2. Good 2 is increasingly expensive in international markets, which implies that the value of marginal product of capital does not fall in country 2 , in spite of diminishing marginal product of capital.

This behavi or of international prices is positive for country 2 by three reasons. First, it allows country 2 achieving sustained growth. Second, country 2 can import more for what it exports, that is get more by less. Third, the improvement in the terms of trade increases country 2's real income and hence welfare. ${ }^{7}$

\footnotetext{
${ }^{7} \mathrm{~T}$ he two latter bene..ts of terms of trade improvements has been identi..ed by $\mathrm{K}$ ohli (2004).
} 


\subsection{Incomplete specialization}

If conditions regarding complete specialization do not hold, the existence of trade requires incomplete specialization of country 1 and, hence, that the terms of trade coincide with relative prices of country 1 in autarky. Under this situation, country 1 produces both intermediates and exports good 1 , while country 2 completely specialize in good 2 . Therefore, the family's problem in country 1 is essentially the same as in autarky, while conditions (17) and (18) of country 2 vanish. We start deriving some results that will be useful to analyze and interpret the long-run equilibrium of the world economy.

As in the previous case, the equilibrium in the trade balance and the maximization of pro..ts by ..rms in the ..nal good sector allow to obtain exported-imported amounts of intermediates by countries:

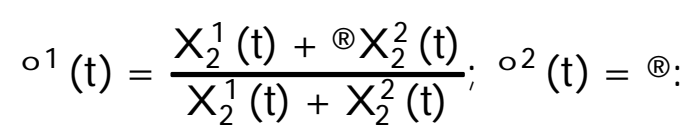

From (28) we obtain that international prices dep end on relative intermediate goods productions, $\frac{p_{1}(t)}{p_{2}(t)}=\frac{\circledast}{l_{i} \otimes} \frac{X_{2}^{1}(t)+X_{2}^{2}(t)}{X_{1}^{1}(t)}$, and that countries's share in gross world income equal $1 / \frac{1}{4}(t)=01(t)$ and $1 / 4(t)=1 ; 01(t)$. In addition, factor allocation in country 1 can be expressed in terms of $0^{1}(t)$ as:

$$
{ }^{1}(\mathrm{t})=\frac{\AA^{\prime}}{\left(\underline{0} 1(\mathrm{t}) ; \quad(\mathbb{R})\left({ }^{\prime}+\tilde{A}\right)+{ }^{\circledR}\right.} ; I^{1}(\mathrm{t})=\frac{\stackrel{\circledR}{0} 1(\mathrm{t})}{}:
$$

Moreover, considering good 2 technologies of countries, factor allocation in country 1 , and the expression of $0^{1}(t)$ in (28), it follows that:

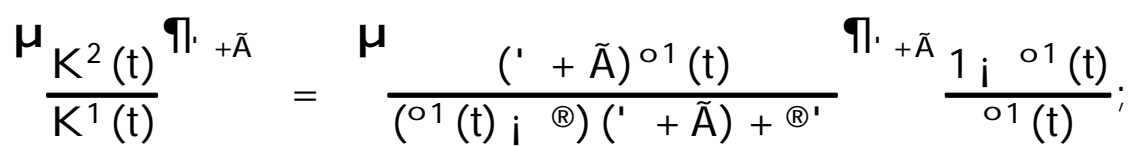

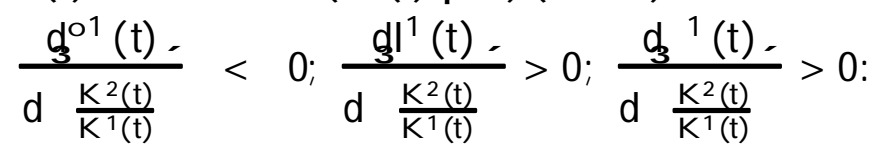

This result tells us that export decision and the factor allocation in country 1 depend on relative amounts of physical capital of countries.

To characterize the long-run equilibrium, we start by imposing constant interest rate in both countries. This requires that physical capital, consumption and gross income in the two economies grow at the same constant rate $\mu$, and human capital grows at the rate $\mu_{H}=\mu_{h}=\frac{1_{i}{ }^{\prime} i_{i}\left(1_{i} \mathbb{B}\right)}{\mathbb{A} A} \mu$ Therefore, the 
long-run equilibrium of the world economy is again a BGP. Expressions for $\mu$ and $u$ are also identical to those in expressions (21) and (22), respectively.

Under incomplete specialization, the BGP replicates the essential equilibrium of a fully integrated world economy, which leads to relative price equalization. Long-run values of $\frac{K^{2}(t)}{K^{1}(t)}$ and, hence, of $0^{1}(t),{ }^{1}(t)$ and $I^{1}(t)$ come from wage and interest rate equalization among countries:

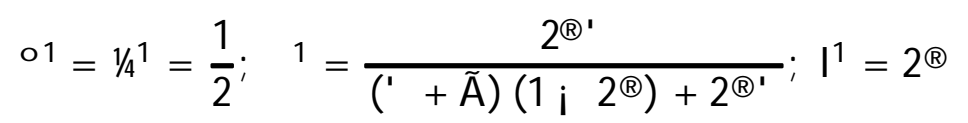

Looking at (31), we check that trade at long-run will be characterized by complete specialization only if ${ }^{\circledR}, \frac{1}{2}$, that is, if country 1 's share in gross world income is greater or equal to one half. Otherwise, country 1 also produce good 2.

From (31) it also follows that countries converge in per capita income. In our model, convergence is due to equalization of all relative prices in both economies. As expression (30) shows, capital and workers in country 1 are allocated so that wage per worker and interest rate equalize among sectors. Since all factor inputs in country 2 are devoted to produce good 2 and labor is ..xed, both factor allocation and export decision in country 1 will depend on countries relative amounts of physical capital. If country 1 capital stock is higher enough that country 2's, then country 1 will devote more resources to produce good 2 and will reduce its exports. The opposite occurs if country 1 capital stock is lower enough that country 2's. Incentives to modify factor allocation and export decision in country 1 cease to exist when $\frac{K^{2}(t)}{K^{\perp}(t)}=\frac{1+\tilde{A}}{(+A)\left(1_{i} 2^{(\Theta)}+2 \Theta\right.}$. Over the BGP, imports from country 2 allow country 1 duplicating the proportion of its workers, and more than duplicate the prop ortion of physical capital to produce good 1, respect to the autarky situation.

We conclude again that trade acts as an engine of growth for country 2 . The explanation on the mechanism of transmission in the previous subsection also applies here. Lastly, convergence in per capita income adds to the three bene..ts that country 2 obtains from the permanent improvement in their terms of trade.

\section{Conclusion}

In this paper, we have explored the possibility of growth transmission through intermediate goods trade. We have shown that growth transmission through 
international trade is possible in absence of spillovers or other type mechanisms that allow developing countries to absorb the technological progress generated in more advanced economies. Though a poor country does not have an own source of sustained growth, trade with a rich country that does have that source leads to growth transmission. This is because the terms of trade become each time more favorable to the ..rst one.

To do this, we have developed a two-country model of endogenous growth in which the rich country accumulates human capital, and therefore its labor productivity improves along time, while the poor country does not invest in human capital. In autarky only the rich country grows, while the poor country behaves as the classical Ramsey economy. Following the comparative advantage theory, both countries enter into trade of intermediate goods. The trade situation may be characterized by complete specialization or incomplete specialization. In either case, the terms of trade become increasingly favorable to the poor country, which takes advantage of productivity gains in the rich country. Thus, human capital accumulation in the rich country acts as an engine of growth for the world economy. Furthermore, trade under incomplete specialization also leads to countries' convergence in per capita income. The crucial assumption in the model to ensure growth transmission is the existence of a non-reproducible factor in the rich country, because it leads to a strictly decreasing time path for rich country's relative prices in autarky.

Our theoretical results agree with the empirical evidence on the terms of trade contribution to growth (e.g.: Barro, 1991; Kohli, 1997), and might be an explanation for the so-called A sian miracle. We then conclude that international trade may have played a relevant role in transmitting growth across countries, and also in making possible countries' convergence in per capita income.

\section{A ppendix A. A utarky}

This appendix shortly describes how the results under autarky have been derived. Since Ramsey's model is known enough, the derivation of the results regarding country 2 is omitted.

Physical capital and workers allocation in expression (20) come from intermediate goods relative prices, and interest rate and wage equalization in sector 1 and 2:

$$
\frac{p_{1}^{i}(t)}{p_{2}^{i}(t)}=\frac{\circledast}{1 ; @ ~} \frac{X_{2}^{i}(t)}{X_{1}^{i}(t)}=\frac{1+\tilde{A}}{K_{1}^{i}(t)} \frac{X_{2}^{i}(t)}{K_{2}^{i}(t)}=\frac{l^{i}(t)}{X_{1}^{i}(t)}=\frac{X_{2}^{i}(t)}{1_{i} l^{i}(t)}=
$$


Over the BGP, the interest rate must be constant to ensure a constant growth rate for consumption:

$$
r^{1}=\frac{(1 ; @)\left({ }^{\prime}+\tilde{A}\right)}{1 i^{1}} \odot{ }^{i} K^{1}(t){ }^{\phi}+\left(1_{i} \circledast\right)^{1}{ }^{1}(H(t))^{\circledR \tilde{A}} i \quad * ;
$$

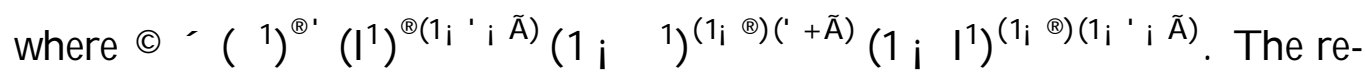
lationship between $\mu$ and $\mu_{H}$ in (21) immediately follows from (A2).

Introducing (10) and the expression for $\mathrm{w}_{1}^{1}(\mathrm{t})$ into (11), and totally differentiating the resulting equation respect to time, we get:

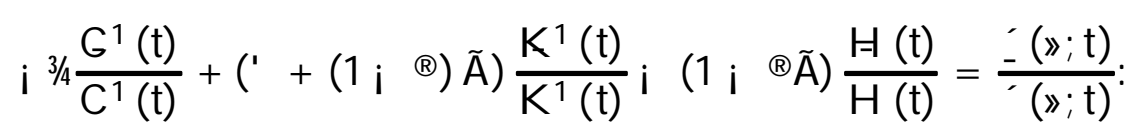

Considering (11), condition (15) can be written as:

$$
\frac{(») ; t)}{(» ; t)}=1 / 2 i i^{\circ}+t_{h}:
$$

Lastly, the value for $\mu$ in (21) comes from plugging (A 4) into (A3) and evaluating the resulting equation over the BGP.

\section{A ppendix B. Trade}

\section{Complete specialization}

Results in (24) and (25) come from pro..ts maximization in the ..nal good sector in country 1 and 2 and the equilibrium in the trade balance:

$$
\frac{P_{1}(t)}{P_{2}(t)}=\frac{\circledast}{1_{i} \otimes} \frac{X_{21}^{2}(t)}{X_{11}^{1}(t)}=\frac{\circledast}{1_{i} \otimes} \frac{X_{22}^{2}(t)}{X_{12}^{1}(t)}=\frac{X_{21}^{2}(t)}{X_{12}^{1}(t)} ;
$$

respectively.

Looking at interest rates of countries at long-run:

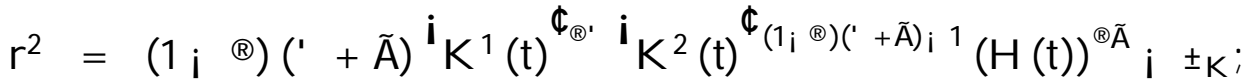

$$
\begin{aligned}
& r^{1}={ }^{\circledR}{ }^{i} K^{1}(t){ }^{\Phi_{\circledast} i} i^{1} i_{K}{ }^{2}(t){ }^{\left.\Phi_{(1 i} \otimes()^{\prime}+\tilde{A}\right)}(H(t))^{\circledR \tilde{A}} i \pm_{K} ;
\end{aligned}
$$

we check that physical capital grows at the same constant rate $\mu$ in both countries, and human capital grows at the higher rate $\mu_{H}$. This implies that interest rate equalizes among countries, which leads to the relationship between capitals in the text. Finally, we solve for the value of $\mu$ foll owing the same steps as in appendix A. 


\section{Incomplete specialization}

As usual, the results in (28) comefrom the dear condition of international markets:

$$
\frac{\mathrm{P}_{1}(\mathrm{t})}{\mathrm{P}_{2}(\mathrm{t})}=\frac{\circledR}{1_{\mathrm{i}} \circledast} \frac{\mathrm{X}_{2}^{1}(\mathrm{t})+\mathrm{X}_{21}^{2}(\mathrm{t})}{\mathrm{X}_{11}^{1}(\mathrm{t})}=\frac{\circledast}{1_{\mathrm{i}} \circledast \mathrm{X}_{22}^{2}(\mathrm{t})}=\frac{\mathrm{X}_{21}^{2}(\mathrm{t})}{\mathrm{X}_{12}^{1}(\mathrm{t})}:
$$

Factor allocation in expression (29) is obtained operating as in appendix A.

Exploiting the fact that the production of good 2 in country 1 can be written as:

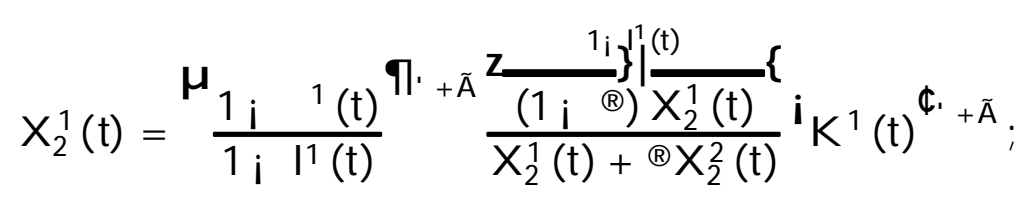

we achieve the result in (30) as follows:

$$
\begin{aligned}
& {\frac{\mu_{i}{ }^{1}(t)}{1 ;\left.\right|^{1}(t)}}^{9 !+\tilde{A}}(1 ; \quad \circledast)^{i} K^{1}(t){ }^{\phi+\tilde{A}}=
\end{aligned}
$$

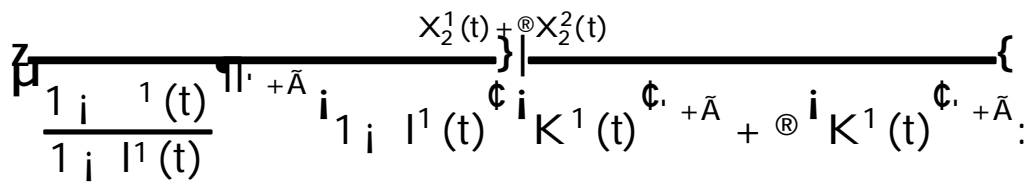

Interest rates of countries over the BGP can be expressed as:

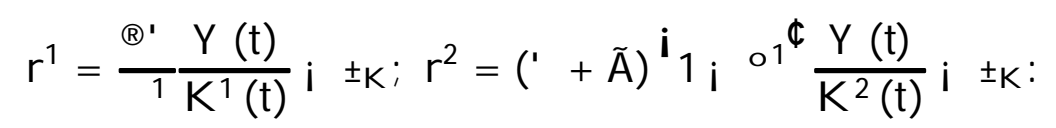

Considering that $X \frac{1}{2}(t)+X \frac{2}{2}(t)=\frac{1}{01}\left(X \frac{1}{2}(t)+{ }^{2} X \frac{2}{2}(t)\right)$ and $(B 4)$, ..nal good world production at long-run can be written as:

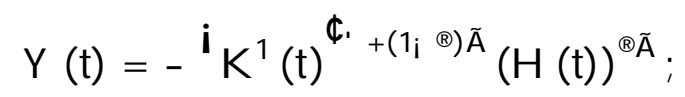

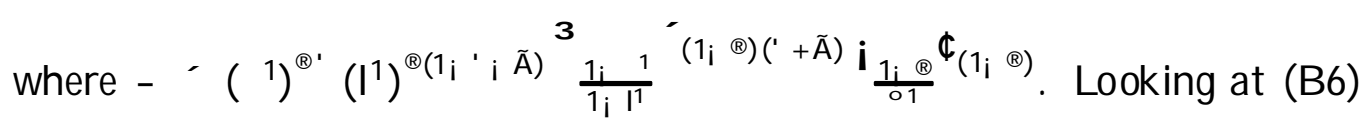
and (B7), it follows that constant interest rates require that physical capital grows at the same rate $\mu$ in both countries, while human capital grows at the 
higher rate $\mu_{H}$. As usual, we follow the same strategy as in appendix A to obtain the value of $\mu$

Lastly, the value for $0^{1}$ comes from interest rate and wage equalization among countries at long-run:

$$
\begin{aligned}
& r^{1}=r^{2} ! \frac{K^{1}(t)}{K^{2}(t)}=\frac{\AA}{1\left({ }^{1}+\tilde{A}\right)\left(1 i^{01}\right)} \\
& w_{2}^{1}=w^{2} ! \frac{K^{1}(t)}{K^{2}(t)}=\frac{\left.1\right|^{1}}{1 i^{1}}:
\end{aligned}
$$

\section{R eferences}

[1] Barro, R. J ., 1991, Economic growth in a cross section of countries, Quarterly J ournal of E conomics, 106 (2), 407-443.

[2] Barro, R. and X. Sala-i-Martin, 1992, Convergence, J ournal of Political Economy, 100, 2, 223-251.

[3] Diewert, W. E., C. J . Morrison, 1986, A djusting output and produtivity indexes for changes in the terms of trade, The E conomic J ournal, 96 (September), 659-679.

[4] Findlay, R., 1980, The terms of trade and equilibrium growth in the world economy, A merican E conomic R eview, 70 (3), 291-299.

[5] Frankel, J. A., D. Romer, and T. Cyrus, 1996, Trade and Growth in East A sian Countries: Causes and Exects?, NBER Working Paper No. 5732.

[6] Grossman, G. M. and E. Helpman, 1997, Innovation and growth in the global economy, (T he MIT P ress, C ambridge).

[7] Kohli, U., 1997, Accounting for recent economic growth in South East A sia, Review of Development Economics, 1 (3) , 245-256.

[8] Kohli, U ., 2004, R eal GDP, real domestic income, and theterms-of-trade changes, J ournal of International Economics, 62 (1), 83-106.

[9] Lewis, W. A., 1954, Economic development with unlimited supplies of Iabour, Manchester School Economic Social Studies, 22 (May), 139-191. 
[10] Lipsey, R obert E ., 1994 Qual ity changeand other In¥uences on measures on export prices of manufactured goods and the terms of trade between primary products and manufactures. NBER Working Paper No. 4671.

[11] Lucas, R. E., 1988, On the mechanics of economics development, J ournal of Monetary E conomics, 22 (1), 3-42.

[12] Mankiw, G., D. Romer and D.N. Weil, 1992, A contribution to the empirics of economic growth, Quarterly J ournal of E conomics, 107, 2, 407-437.

[13] Ortigueira, S. and M. Santos, 1997, On the speed of convergence in endogenous growth models, A merican E conomic Review, 87, 3, 383-399.

[14] Rebelo, S., 1991, long run policy analysis and long run growth, J ournal of Political E conomy, 99 (3), 500-521.

[15] Solow, R. M., 1956, A contribution to the theory of economic growth, Quarterly J ournal of E conomics, 70, 65-94.

[16] Ventura, J., 1997, Growth and Interdependence, Quarterly J ournal of E conomics, 112 (1), 57-84.

[17] Young, A., 1995, The tyranny of numbers: Confronting the statistical realities of the East A sian growth experience, Quarterly J ournal of Economics, 110 (3), 641-680.

[18] United Nations, Statistics Division, 2004. System of National Accounts 1993. http:/ / unstats.un. org/ unsd/ sna1993/ glossary.asp 